\title{
CHARACTERISTICS OF ENERGY AND PROTEIN FOODS. A REPORT
}

\author{
Gil Dutra FURTADO ${ }^{1 *}$; Andrei Felipe Loureiro do Monte GUEDES ${ }^{2}$
}

\author{
${ }^{1}$ Veterinary Medicine student/Maurício de Nassau University Center (UNINASSAU-PB), João Pessoa, Paraíba; \\ Agronomist/Federal University of Paraíba (UFPB); Ph.D. in Psychobiology/Federal University of Rio Grande do \\ Norte (UFRN); Socio-partner of the Agribusiness Cooperative (COOPAGRO), Natal, Rio Grande do Norte, \\ Brazil. \\ ${ }^{2}$ Professor of Animal Nutrition/UNINASSAU-PB, João Pessoa, Paraíba, Brazil. \\ *Correspondence author. E-mail: gdfurtado@hotmail.com
}

\begin{abstract}
The feed formulation is a tool of great importance for technicians and producers of domestic animals, since the nutritional requirements of animals must be met, so that they can present a good productive and reproductive performance, directly related to viability, technical and economic value of the animal production system. Veterinary medicine students, during the animal nutrition discipline, had the opportunity to study concentrates, which is reported in this article.
\end{abstract}

Keywords: Concentrates; Management; Students.

\section{CARACTERISTICAS DE ALIMENTOS ENERGÉTICOS E PROTEICOS. UM RELATO}

Resumo. A formulação de ração é uma ferramenta de grande importância para técnicos e produtores de animais domésticos, já que as exigências nutricionais dos animais devem ser atendidas para que os mesmos possam apresentar um bom desempenho produtivo e reprodutivo, o que está diretamente relacionado com a viabilidade técnica e econômica do sistema de produção animal. Estudantes de Medicina veterinária, durante a disciplina de nutrição animal, tiveram a oportunidade de estudar sobre os concentrados, que é o relatado neste artigo.

Palavras-chave: Concentrados; Manejo; Estudantes.

\section{CARACTERÍSTICAS DE LOS ALIMENTOS DE ENERGÍA Y PROTEÍNA. UN INFORME}

Resumen. La formulación del alimento es una herramienta de gran importancia para los técnicos y productores de animales domésticos, ya que los requisitos nutricionales de los animales deben cumplirse para que puedan presentar un buen rendimiento productivo y reproductivo, directamente relacionado con la viabilidad. Valor técnico y económico del sistema de producción animal. Los estudiantes de medicina veterinaria, durante la disciplina de nutrición animal, tuvieron la oportunidad de estudiar concentrados, que se informa en este artículo. 
Palabras clave: Concentrados; Gestión; Estudiantes.

\section{INTRODUCTION}

Veterinary medicine students have a great responsibility of study in the objective of learning how to instruct tutors and breeders of animals, among others, after their professional training, aiming at the welfare of animals and the prevention of the many pathologies related to nutrition. Thus, the academics of the Maurício de Nassau University Center (UNINASSAU), located at municipality of João Pessoa, State of Paraíba, Northeast Brazil, seek to absorb the various teachings in the discipline of Animal Nutrition, in order to be good professionals. Among the many classes, a theme addressed was about concentrates, which is described in this job (FURTADO; SILVA; TELES, 2018).

To make livestock competitive in relation to production systems, efforts must be made to apply technologies aimed at intensifying it, aiming at reducing livestock farming area and maximizing profits, which are closely linked to the management adopted for herd feeding, since these costs represent between $40 \%$ and $60 \%$ (or more) of the total cost of production (BERCHIELLI; PIRES; OLIVEIRA, 2006).

Thus, the planning of nutritional management of the herd will contribute to avoid unnecessary expenses, favoring the expansion of profits from livestock activity. This food planning, however, is dependent on knowledge about the nutritional potential of foods made available to herds, the nutritional requirements of animals and their categories, and basic knowledge for feed formulation (BRITO; NOBRE; FONSECA, 2009).

This work aimed to sum up characteristics of energy and protein foods, providing important information for the academic learning of future veterinarians in training at the Maurício de Nassau University Center.

In order to better understand the concentrates, we initially found out that the bulky lysines are those foods with low energy content, but with high levels of fiber or water. These carry less than $60 \%$ of total digestive nutrients (TDN) and crude fiber of $18 \%$ or more. These can be divided into dry and damp (CAPPELLE, 2000).

In the properties of extensive breeding, the most used are the natural or artificial pastures such as Brachiaria and Panicum in most, also weeding, such as those formed by elephant grass, silages (grass, corn, sorgo or others), sugarcane, hydrogen bagasse hydrolyzed among others. And the least used are the millet, grass hays, sunflower silage, crop straws etc (FERREIRA, 2019). 
The concentrated foods usually contain low water and fiber content, but are those with high energy content, possessing more than $60 \%$ NDT and less than $18 \% \mathrm{FB}$, being divided into energetic and protein (ESTEVES, 2000).

Concentrates and energetics are foods with less than $20 \%$ Protein Concentrate (PC), which has as an example of these corn, serum, wheat, rice, molasses, citrus pulp; and of animal origin, tallow and animal fat (FERREIRA, 2019)

Protein concentrates of vegetal origin are foods with more than $20 \% \mathrm{PC}$, which has plant origin in soybean bran, cottonseed, sunflower meal, soybean grain, peanut meal, cottonseed, among others. Those of animal origin are blood meal, fish meal, meat meal, bone meal, among, others (FERREIRA, 2019).

With this information in mind, the diet for animals in general should be well known by veterinarians, since they are professionals who have the responsibility of providing a good diet for animals, aiming at adequate nutrition, preventing pathologies and harm to owners, while conferring animal welfare so important in the entire productive chain (VASCONCELOS, 2008).

\section{CONCLUSIONS}

Academic activities are important educational tools, presenting the reality of the importance of nutrition and its many particularities.

The veterinary medicine course addressing this and enabling it, offers a valuable opportunity to enable academics to see more closely the importance of nutrition for animal welfare and for better genetic expression of herds.

\section{REFERENCES}

BERCHIELLI, T.T.; PIRES, A.V.; OLIVEIRA, S.G. Nutrição de ruminantes. Jaboticabal. FAPESP, 2006.

BRITO, A.S.; NOBRE, F.V.; FONSECA, J.R.R.F. Bovinocultura leiteira: informações técnicas e de gestão. SEBRAE/RN, 320 p. 2009.

\section{CAPPELLE, E.R. Tabelas de composição dos alimentos, estimativa do valor energético e} predição do consumo e do ganho de peso de bovinos. Tese (Doutorado em Zootecnia) Departamento de Zootecnia da Universidade Federal de Viçosa, Minas Gerais: UFV, 369p. 2000 . 
ESTEVES, S.N. Concentrados proteicos e energéticos mais utilizados na formulação de rações para bovinos. In: XIV Semana do Estudante, São Carlos-SP: EMBRAPA Sudeste. p. 72-79, 2000 .

FERREIRA, A.M.S. Consumo observado e predito pelos sistemas nutricionais em bovinos de corte confinados. Mestrado (Dissertação, Pós-Graduação em Ciências Veterinárias da Universidade Federal de Uberlândia) Uberlândia, Minas Gerais, p. 69. 2019.

FURTADO, G.D.; SILVA, A.S.; TELES, J.A.A. Estudo do comportamento e a medicina veterinária da conservação. Environmental Smoke, João Pessoa, v. 1, n. 2, p. 176-182, 2018.

VASCONCELOS, R.M.J. Manejo reprodutivo em vacas leiteiras. In: Bovinocultura Leiteira. EMPARN, Natal, 2008. 